\title{
BLOOD CLOTTING AND FIBRINOLYSIS IN AREAS WITH DIFFERENT WATER SUPPLIES
}

\author{
P. C. ELWOOD1, M. A. CHADD ${ }^{2}$, M. BURR ${ }^{1}$ AND L. M. HAYMAN2 \\ MRC Epidemiology Unit, Cardiff 1 and the Department of Child Health, \\ University Hospital of Wales ${ }^{2}$
}

There is an apparent association between water hardness and mortality from cardiovascular disease (Kobayashi, 1957; Crawford, Gardner, and Morris, 1968). This association may arise because of an effect of water on a known 'risk factor' such as blood pressure, or the susceptibility of the myocardium could be affected, or some process relevant to intravascular thrombosis could be involved.

In an earlier study (Elwood et al., 1971) we presented data which showed no evidence of any important difference in certain of the known 'risk factors' such as serum cholesterol and blood pressure, or in two measures of the excitability of the myocardium (QT interval and the presence of extrasystoles). In this paper we present data relating to blood clotting and fibrinolysis.

\section{METHOD}

Two villages, one of which has a hard water supply (350-380 p.p.m. total hardness) and the other a soft water supply (around 30-40 p.p.m.), were chosen. Random samples of male and female electors were selected and asked to co-operate.

A sample of venous blood was taken from each subject. Some of this $(5 \mathrm{ml})$ was mixed with fresh $3 \cdot 8 \%$ sodium citrate, $9: 1$ volumes blood to citrate, spun immediately at 3,000 r.p.m. for 10 minutes in a MSE centrifuge and the plasma was separated and deep frozen immediately. Two millilitres of blood were mixed with $20 \mu$ l of Trasylol and allowed to clot overnight, and then the serum was separated and deep frozen.

Clinics were arranged on two days each week, one day in the hard and the other day in the soft water area, and the order of the clinics each week was alternate. Care was taken to ensure that the blood and serum samples were always handled in exactly the same way. Samples were numbered at random and submitted to the laboratory in batches ${ }_{i}^{+}$ of roughly equal numbers from the two areas. All $\vec{\sigma}$ laboratory work on the samples was therefore doneo without knowledge of the area of their origin, and all tests were completed within a few days of taking $z$ the blood.

In order to obtain further data on fibrinolysis $\frac{\mathbb{D}}{3}$ five other hard water areas (all with supplies over@ 240 p.p.m.) and five with soft water (all under 70 p.p.m.) were selected and a further 910 subjects were seen in exactly the same way as in the mañ ? study, though only estimations of fibrin degratdation products were made.

The tests used were the thrombin clotting time and the kaolin cephalin clotting time estimated by $\frac{\mathrm{O}}{\mathrm{D}}$ standard methods. Circulating fibrinogen and $\stackrel{\varrho}{\rightarrow}$ plasminogen were estimated by a modification of $\overrightarrow{\overrightarrow{0}}$ standard immunological methods of Wolf (personal communication); clotting fibrinogen was also estimated by the method of Farrell and Wolf (1971). Fibrin degradation products were estimated by the Wellcome modification of the methods of Mura-? kami, Sekimoto, and Yasuda (1965) and Merskey, $\frac{5}{3}$ Kleiner, and Johnson (1966). Because the estimation.of fibrinogen and plasminogen is tedious and supplies $ᄋ$ of the necessary immune sera are limited, these were made only on a subsample of the male subjects, $\frac{\text { a }}{2}$ chosen at random from all those seen.

\section{RESULTS}

The number of subjects seen is shown in Table I. The mean ages of the groups are very similar. The results of the two clotting tests are also shown in $\omega$ Table $I$ and the mean levels of fibrinogen and plasminogen in Table II. There is no evidence of any differences likely to be clinically important. Table III summarizes the data for fibrin degradation ${ }^{+}$ products. Because the distribution of these estimations in original units $(\mu \mathrm{g} / \mathrm{ml})$ shows very marked $\stackrel{\oplus}{\mathbb{\Phi}}$ 
TABLE I

MEANS ( \pm S.E.) OF AGE (YR) AND CLOTTING TIMES (SEC) IN THE TWO AREAS

\begin{tabular}{|c|c|c|c|c|c|c|c|c|}
\hline & \multicolumn{4}{|c|}{ Hard Water Area } & \multicolumn{4}{|c|}{ Soft Water Area } \\
\hline & No. & Age & T.C.T. & K.C.C.T. & No. & Age & T.C.T. & K.C.C.T. \\
\hline Males & 42 & $47 \cdot 3 \pm 2 \cdot 31$ & $12 \cdot 1 \pm 0 \cdot 27$ & $44.5 \pm 0.52$ & 42 & $47 \cdot 6 \pm 2 \cdot 37$ & $11.8 \pm 0.32$ & $45.4 \pm 0.73$ \\
\hline Females & 58 & $46 \cdot 8 \pm 2 \cdot 24$ & $11 \cdot 2 \pm 0.17$ & $46.1 \pm 0.85$ & 75 & $46.2 \pm 1.86$ & $11.2 \pm 0.17$ & $46.2 \pm 0.65$ \\
\hline
\end{tabular}

TABLE II

MEAN LEVELS ( $t$ S.E.) OF SERUM FIBRINOGEN AND PLASMINOGEN $(\mu \mathrm{g} / \mathrm{ml})$ IN 21 MALE SUBJECTS

\begin{tabular}{l|r|r}
\hline & Hard Water Area & Soft Water Area \\
\hline $\begin{array}{l}\text { Fibrinogen } \\
\text { (immunological method) }\end{array}$ & $149.0 \pm 9.82$ & $151.6 \pm 10.01$ \\
$\begin{array}{l}\text { Clottable fibrinogen } \\
\text { (clottable method) }\end{array}$ & $319.3 \pm 18.03$ & $318.3 \pm 13.30$ \\
$\begin{array}{l}\text { Plasminogen } \\
\text { (immunological method) }\end{array}$ & $6.7 \pm 0.60$ & $7.6 \pm 0.62$ \\
$\begin{array}{l}\text { Plasminogen } \\
\text { (lytic method) }\end{array}$ & $7.6 \pm 0.64$ & $6.5 \pm 1.52$ \\
\hline
\end{tabular}

TABLE III

MEAN LEVELS ( \pm S.E.) OF FIBRIN DEGRADATION PRODUCTS IN HARD AND SOFT WATER AREAS

\begin{tabular}{|c|c|c|c|c|}
\hline Area & Sex & No. & $\begin{array}{c}\text { Transformed } \\
\text { Data } \\
\text { (log. to } \\
\text { base 10) }\end{array}$ & $\begin{array}{c}\text { Transformed } \\
\text { Mean in } \\
\text { Original Units } \\
(\mu \mathrm{g} / \mathrm{ml})\end{array}$ \\
\hline $\begin{array}{l}\text { Main study } \\
\text { Hard water area }\end{array}$ & $\stackrel{\mathbf{M}}{\mathbf{F}}$ & $\begin{array}{l}41 \\
57\end{array}$ & $\begin{array}{l}0.63 \pm 0.048 \\
0.66 \pm 0.050\end{array}$ & $\begin{array}{l}4 \cdot 3 \\
4 \cdot 6\end{array}$ \\
\hline Soft water area & $\stackrel{\mathbf{M}}{\mathbf{F}}$ & $\begin{array}{l}42 \\
75\end{array}$ & $\begin{array}{l}0.67 \pm 0.062 \\
0.77 \pm 0.045\end{array}$ & $\begin{array}{l}4 \cdot 7 \\
5 \cdot 9\end{array}$ \\
\hline $\begin{array}{l}\text { Further study } \\
\text { Hard water area }\end{array}$ & $\underset{\mathbf{F}}{\mathbf{M}}$ & $\begin{array}{l}147 \\
280\end{array}$ & $\begin{array}{l}0.38 \pm 0.067 \\
0.46 \pm 0.069\end{array}$ & $\begin{array}{l}2 \cdot 6 \\
3 \cdot 2\end{array}$ \\
\hline Soft water area & $\underset{\mathbf{F}}{\mathbf{M}}$ & $\begin{array}{l}157 \\
326\end{array}$ & $\begin{array}{l}0.32 \pm 0.062 \\
0.52 \pm 0.078\end{array}$ & $\begin{array}{l}2 \cdot 2 \\
3 \cdot 7\end{array}$ \\
\hline
\end{tabular}

positive skewness, the means and estimates of dispersion have been obtained following transformation to logarithms to base 10 . However, mean levels in original units, obtained from the transformed data, are also shown. In the main study mean levels in both males and females in the soft water area are higher than in the hard water area, but neither difference is statistically significant at $\mathbf{P}<0.05$. However, the data obtained in the further studies do not confirm this, and neither is statistically significant.

\section{Discussion}

The hypothesis that the difference in mortality in hard and soft water areas is due to some difference in one of the processes involved in intravascular thrombosis is attractive. The difference was first noticed for deaths attributed to cerebrovascular accidents (Kobayashi, 1957) and although the greatest interest is now in the link with myocardial infarction the effect is apparent for all the more common cardiovascular causes of death. Although an effect on any of several mechanisms could lead to this observed mortality pattern, an enhancement of intravascular thrombosis seems a likely common link in all of these conditions. Furthermore, trace elements are known to be involved at several stages in intravascular thrombosis.

Unfortunately, thrombosis is a very complex and ill-understood process, and most of the relevant tests are unsuitable for use in field studies. We have, however, attempted to examine several aspects of intravascular thrombosis. Although the numbers of tests are small, the results of the clotting tests give no evidence of any association with water supply, nor do the estimates of serum fibrinogen or plasminogen.

Although the estimates of fibrin breakdown products in the main study did show differences which are in the same direction in males and females, these results were not confirmed by the much larger further studies. Unfortunately, we did not collect details from the women relating to menstruation and contraceptive pill taking. We do know that no woman was in an advanced stage of pregnancy and we have assumed that in each area an equal proportion was in each phase of the menstrual cycle. We have also assumed that similar proportions of women were on oral contraceptives and since the communities surveyed in the various areas were very similar this does not seem to be an unreasonable assumption.

The number of subjects in these studies is small and it would be unwise to draw firm conclusions. However, the general pattern of the results indicates 
that it is unlikely that an effect of water supply on cardiovascular mortality occurs through the clotting or the fibrinolytic mechanism.

\section{SUMMARY}

The thrombin clotting time, the kaolin cephalin clotting time, the levels of circulating fibrinogen and plasminogen, and the level of fibrin degradation products were estimated in random samples of subjects living in areas with a hard and a soft water supply (about 370 and 40 p.p.m. respectively). The level of fibrin degradation products showed small differences suggestive of increased fibrin deposition in the soft water area, but further studies on other population samples failed to confirm this difference. There was no evidence of any difference in the other tests which are likely to be of clinical importance.

We wish to acknowledge the help and encouragement of our colleagues in the Epidemiology Unit and the Department of Child Health, in particular Professors A. L. Cochrane and O. P. Gray. Dr. A. L. Bloom and Dr. P. Wolf gave advice and technical assistance.

\section{REFERENCES}

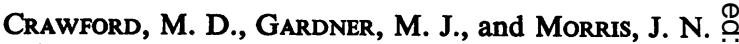
(1968), Mortality and hardness of local water-supplies. Lancet, $1,827$.

Elwood, P. C., Bainton, D., Moore, F., Davies, D. F., Wakiey, E. J., Langman, M., and Sweetnam, P. (1971). Cardiovascular surveys in areas with different water supplies. Brit. med. J., 2, 362.

FARRell, G. W., and Wolf, P. (1971). The measurement of fibrinogen and its derivatives. 1. Examination of methods of measurement of clottable fibrinogen. J. med. Lab. Technol., 28, 310.

Kobayashi, J. (1957). On geographical relationship between the chemical nature of river water and deathrate from apoplexy. Ber. Ohara Inst. landw. Biol., $11,12$.

Merskey, C., KLeiner, G. J., and Johnson, A. J. (1966). Quantitative estimation of split products of fibrinogen in human serum, relation to diagnosis and treatment. Blood, 28, 1.

Murakami, M., Sekimoto, H., and Yasuda, Y. (1965). A new method for the determination of fibrinolytic activity by means of immuno-assay of breakdown products of fibrin and fibrinogen. Jap. J. clin. Path., 13, 542. 